\title{
Helminth parasites of bats (Chiroptera, Phyllostomidae) in the Department of Junin, Peru and Check list of records made in Peru
}

\author{
David MINAYA ANGOMA ${ }^{1}$, Gloria M. SAEZ FLORES ${ }^{2}$, Jhon CHERO DE LA CRUZ ${ }^{2}$, \\ Celso CRUCES CHANCAHUAÑ ${ }^{2}$, José IANNACONE ${ }^{1,3}$
}

\begin{abstract}
${ }^{1}$ Laboratorio de Ecología y Biodiversidad Animal. Facultad de Ciencias Naturales y Matemática. Universidad Nacional Federico Villarreal. Jr. Río Chepén 290, El Agustino, Lima 15007, Perú. ${ }^{2}$ Laboratorio de Parasitología. Facultad de Ciencias Naturales y Matemática. Universidad Nacional Federico Villarreal. Jr. Río Chepén 290, El Agustino, Lima 15007, Perú. ${ }^{3}$ Laboratorio de Ingeniería Ambiental. Facultad de Ciencias Ambientales. Universidad Científica del Sur. Carr. Panamericana Sur 19, Villa el Salvador, Lima 15067, Perú. Corresponding author: José Iannacone, joseiannacone@gmail.com
\end{abstract}

\begin{abstract}
The objective of this work was to determine the parasitic helminth fauna of the phylostomid bats of Junin, Peru, as well as to prepare an updated checklist of records made in Peru. Thirty bats of 6 different species belonging to the family Phyllostomidae were captured in the locality of Chanchamayo, Junin, Peru. Of these species, Artibeus lituratus Olfers, 1818, A. planirostris (Spix, 1823) and Carollia perspicillata (Linnaeus, 1758) were parasitized by trematodes and nematodes; Phyllostomus discolor (Wagner, 1843) by cestodes and nematodes; Carollia benkeithi Solari \& Baker, 2006 and Glossophaga soricina (Pallas, 1766) by nematodes. A total of 175 trematode specimens, 115 nematode specimens and 8 cestode specimens were collected. All parasites found in the survey are new records for the department of Junin. The checklist developed in this study found 26 parasite species in the literature. Litomosoides brasiliensis Almeida, 1936, was the endoparasite with the largest number of hosts. The number of hosts with at least one species of parasite recorded was 22 bat species on the checklist.
\end{abstract}

Key words: Bats, Host, Litomosoides, parasites, Phyllostomidae

Resumen: Helmintos parásitos de murciélagos (Chiroptera, Phyllostomidae) en el Departmento de Junín, Perú y una lista de verificación de los registros realizados en Perú. El objetivo de este trabajo fue determinar la fauna de helmintos parásitos de los murciélagos filostómidos de Junín, Perú, así como preparar una lista de verificación actualizada de los registros realizados en el Perú. Treinta murciélagos de 6 especies diferentes pertenecientes a la familia Phyllostomidae fueron capturados en la localidad de Chanchamayo, Junín, Perú. De estas especies, Artibeus lituratus Olfers, 1818, A. planirostris (Spix, 1823) y Carollia perspicillata (Linnaeus, 1758) fueron parasitados por trematodos y nematodos; Phyllostomus discolor (Wagner, 1843) por cestodos y nematodos; Carollia benkeithi Solari \& Baker, 2006 y Glossophaga soricina (Pallas, 1766) por nematodos. Fueron colectados 175 especímenes de trematodos, 115 especímenes de nematodos y 8 especímenes de cestodos. Todos los parásitos hallados en el relevamiento son nuevos registros para el departamento de Junín. En la lista de verificación desarrollada en este estudio se encontraron 26 especies de parásitos en la literatura. Litomosoides brasiliensis Almeida, 1936, fue el endoparásito con el mayor número de hospedadores. El número de hospederos con al menos una especie de parásito registrado es de 22 especies de murciélagos en la lista de verificación.

Palabras clave: Hospedador, Litomosoides, Murciélagos, Parásitos, Phyllostomidae

\section{INTRODUCTION}

Chiroptera are not only important for their great terrestrial diversity, but also for playing ecological roles as prey and predator, arthropod suppression, soil fertility and nutrient distribution, and recycling (Jones et al., 2003; Wund \& Myers, 2005; Kasso \& Balakrishnan, 2013; Mello et al., 2015; De Albuquerque et al., 2016). Bats having an economic and health value because they naturally control agricultural pests and disease-transmitting insects, and because they help to pollinate and disperse seeds of various plant species. Bats also are considered good indicators of environmental stress (Eisenberg \& Redford, 2000; Datzmann et al., 2010; Díaz et al., 2011; De 
Albuquerque et al., 2016; Díaz et al., 2016).

The chiropterans, being a highly diversified group in relation to species and food habits, are not oblivious to helminth parasitosis, because bats usually acquire these parasites passively through their diet, with the digestive tract and body cavity being the most parasitized by helminths (Gregory et al., 1996; Cuartas-Calle \& Muñoz-Arango 1999; Poulin \& Morand 2004).

Parasitic helminths of Chiroptera can be associated with intrinsic factors (age, body size, gender, individual genetic aspects, immune response, foraging strategy and nutritional status) and extrinsic factors (social structure, behavior patterns, distribution areas, activity areas, migration and evolutionary history) of the hosts and their habitats (Esteban et al., 1991; Poulin \& Morand, 2004; Pinheiro et al., 2013; De Albuquerque et al., (2016). Among these studies it has been observed that bats can act as definitive hosts (e.g. Vampirolepis) and intermediaries (e.g. Physocephalus $\mathrm{L}_{3}$ ) for parasitic helminths. (Walldorf \& Mehlhorn, 2014; Falconaro et al., 2018).

In relation to these investigations that have been registered in relation to parasitism in Chiroptera, only about one-third of the species of bats known in South America have been reported to have helminths; likewise, in Peru fourteen parasitic helminth species have been reported from bats (Santos \& Gibson, 2015).

Studies related to the biology and ecology of Chiroptera have increased in recent decades, including studies related to the helminth parasites and their high specificity within these hosts (Hill \& Smith, 1984; Dick, 2007; Díaz et al., 2011; Frank et al., 2014).

In Peru, the first studies related to parasitic helminths of Chiroptera were done by Freitas and Ibañez (1963), who carried out parasitological studies on the mouse-tailed bat Talarida brasiliensis (I. Geoffroy, 1824) (Molossidae) in the department of La Libertad (Vargas et al., 2009a).

Within this context, this research aimed to determine the parasitic helminth fauna of Phyllostomid bats from Fundo San José, Chanchamayo, Junin, Peru, as well as to prepare an updated check list of records made in Peru.

\section{MATERIALS AND METHODS}

Study area. Bats were captured in April 2013 and May 2014, to $5 \mathrm{~km}$ from downtown La Merced, at three points of capture $\left(11^{\circ} 04^{\prime} 12^{\prime \prime} \mathrm{S}\right.$,
75²0'37'W; $11^{\circ} 04^{\prime} 11^{\prime \prime S}, 75^{\circ} 20^{\prime} 37^{\prime \prime} \mathrm{W} ; 11^{\circ} 04^{\prime} 16$ "S, $75^{\circ} 20^{\prime} 36^{\prime \prime} \mathrm{W}$ ), these localities corresponds to the Yungas-Montane forests of the eastern slope of the Andes of Peru, Chanchamayo locality, Chanchamayo province, Junin department, Peru (Fig. 1).

Host bats. Mist nets of $10 \times 2.5$ m were installed among the trees near crops, always trying to obstruct the most likely entrance that the bats could have. Monitoring of the nets was made between 22:00 h-02:00 h at 30-minute intervals, following the methodology of Pacheco et al. (2007). For the identification of the hosts, the taxonomic keys of Ibáñez (1981), Eisenberg \& Redford (2000), Pacheco et al. (2007) and Díaz et $a l$. (2016) were used. The bats collected were deposited in the Colección Zoológica of the Museo de Historia Natural of the Professional School of Biology, Facultad de Ciencias Naturales y Matematica, Universidad Nacional Federico Villarreal (MUFV-ZOO), Lima, Peru. According to the IUCN Red List of Threatened Species, all species of bats collected in this study showed a state of conservation of Less Concern. The collection was authorized by Directorial Resolution $\mathrm{N}^{\circ}$ 024-2014-SERFOR-DGGSPFFS.

Endoparasite helminths. For the collection of endoparasitic helminths, the abdominal cavity, thoracic cavity, lungs, stomach, small intestine, large intestine, gonads, heart, gallbladder, liver and spleen were examined (Lamothe, 1997). Nematodes were fixed in $70 \%$ boiling ethyl alcohol, and trematodes and cestodes pre-pressed between two slides and fixed with $4 \%$ formalin for $24 \mathrm{~h}$; they were then stored in $70 \%$ ethyl alcohol for transfer to the laboratory (McAllister et al., 2005). The trematodes and cestodes were stained in Semichon's acetic carmine and mounted in Canada balsam. In the identification of the nematodes alcohol-phenol was used to clarify the cuticle and observe in detail the copulatory structures of males and other important structures in both sexes (Oviedo et al., 2010).

The nomenclature and classification of trematodes was done following Thatcher (1993), Bray et al. (2008) and Fernandes et al. (2015), for cestodes, Khalil et al. (1994) and for nematodes Durette-Desset \& Vaucher (1989) and Guerrero et $a l$. (2002). In addition, the prevalence (\% P), mean abundance (MA) and mean intensity (MI) for each parasitic species were calculated following Bush et al. (1997) and Bautista-Hernández et al. (2015), and were evaluated using the statistical 


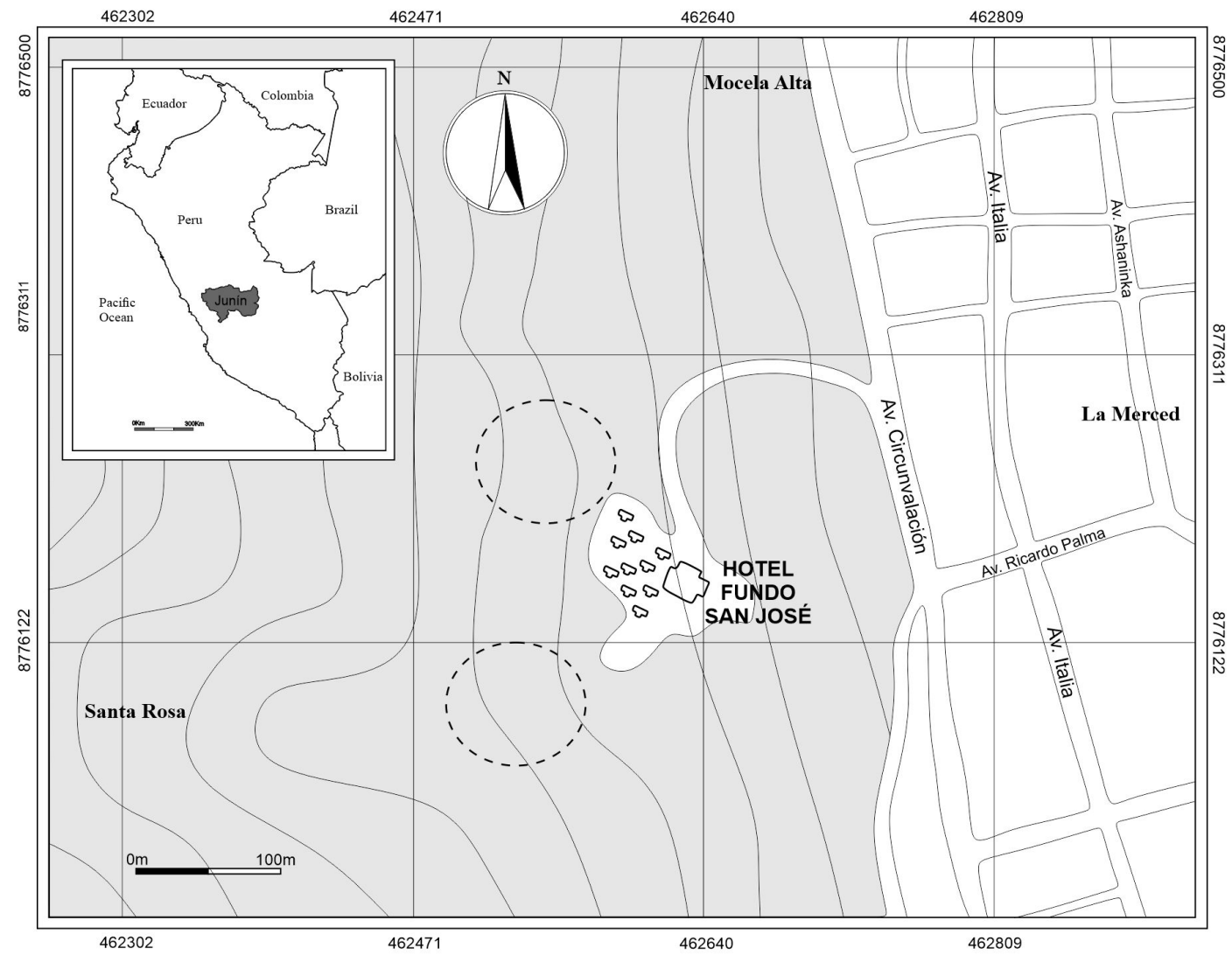

Fig. 1. Study area in the jungle of Junin, Peru. Circles with dotted lines are the sampling area.

package Quantitative Parasitology 3.0 (Rózsa et al., 2000).

All the specimens studied were deposited in the Colección de Helmintos parásitos e invertebrados afines of the Museo de Historia Natural (MUFV: ZOO: HPIA), Universidad Nacional Federico Villarreal, Lima, Peru and in the Museo de Historia Natural (MUSM), Universidad Nacional Mayor de San Marcos, Lima, Peru.

List of parasitic helminths of the bats of Peru. The parasite-host lists of the parasitic bat helminths of Peru presented in this work were compiled from data obtained from searches of the literature in physical libraries of the Peruvian's universities, scientific collections, and museums, and in the virtual literature in databases such as the Web of Science, Scopus, Scielo, Helminthological Abstracts, Research Gate and Google Scholar (Martín-Martín et al., 2018). The list elaborated in this study is composed of taxonomic classifications of the parasites, the hosts registered in Peru and their respective trophic guild, the site of infection, locality, i.e., the governmental department in which the parasitized host was reported, and the bibliographic reference. The abbreviations correspond to the trophic guild of the host: low-flying insectivore LFI, high-flying insectivore HFI, insectivore-piscivore IPI, omnivore-nectivorous OMN, high-flying frugivore HFF, low-flying frugivore LFF, insectivore-carnivore INC, hematophagous (HEM) and omnivore-predator OMP (Patterson et al., 1996).

Ethical aspects. The procedures for collecting parasitic fauna in the bats followed the guidelines of the "Institutional Animal Care and Use Committee" (IACUC) (APA 2012), minimizing the number of organisms used, repetitions and using the three $\mathrm{Rs}_{\mathrm{s}}$ "-replacement, reduction, and refinement", and resolution 2558-2018CU-UNFV that includes the code of ethics for research at the Universidad Nacional Federico Villarreal (UNFV). For the management of the parasitic fauna, the guidelines of the protection 
and animal welfare law of Peru were followed (Law No. 30407: Article 19). The collection of the parasitic fauna is indicated by the SERFOR (Servicio Nacional Forestal y de Fauna Silvestre) of Peru that establishes the guidelines for the scientific investigation of flora and/or wild fauna (Resolution of Executive Direction №060-2016 SERFOR-DE). For the field collection of the bats, the impact on the abundance of species was minimized so that it is minimal (Costello et al., 2016).

\section{RESULTS}

Thirty specimens of bats belonging to the Phyllostomidae family were captured: one individual from Artibeus lituratus (Olfers, 1818), 4 individuals of Artibeus planirostris (Spix, 1823), 1 individual of Carollia benkeithi Solari \& Baker 2006, 20 individuals of Carollia perspicillata (Linnaeus, 1758), 2 individuals of Glossophaga soricina (Pallas, 1766) and 2 individuals of Phyllostomus discolor (Wagner, 1843).

Seventeen of thirty (56.7\%) individuals of the examined bats were found to be parasitized, distributed as follows: 6 individuals were parasitized by trematodes (19.4\%), 1 individual by cestodes $(3.2 \%)$, and sixteen individuals by nematodes $(51.61 \%)$ (Table 1). Of the population studied, 6 specimens presented polyparasitism, of which 5 were parasitized by Anenterotrema iannaconei Achatz, Cardenas-Callirgos \& Tkach, 2018 and Litomosoides brasiliensis Almeida, 1936 and 1 specimen by L. brasiliensis and Carostrongylus touzeti Durette-Desset \& Vaucher, 1989.

Regarding the parasites, 175 trematode specimens, 115 nematode specimens and 8 cestode specimens were collected. All the parasites mentioned in the paper are new records for the department of Junin.

Nematoda

Molineidae Durette-Desset \& Chabaud, 1977

Carostrongylus Durette-Desset \& Vaucher, 1989

Carostrongylus touzeti Durette-Desset \& Vaucher, 1989

(Fig. 2A-B)

Materials examined. Peru: Junin: Chanchamayo: La Merced, $11^{\circ} 04^{\prime} 12$ "S, 75²0'37”W, 11-12. vii.2016, Minaya, D. (MUSM-3591, MUFV:ZOOHPIA:1).

Host. Carollia perspicillata (20 evaluated, 1 infected), Peru: Junin: Chanchamayo: La Merced,
1104'12”S $\quad 75^{\circ} 20^{\prime} 37^{\prime \prime} \mathrm{W}, \quad$ 10-15.iv.2013, 2126.v.2014. Guabloche A. (MUFV-ZOO7).

Site of infection. Small intestine.

Identification. Based on 4 individuals (3 males, 1 female). Cephalic extremity without cuticular spines, with simple vesicle, wider than long. Synlophe little developed. Male: Lobes and lateral rays of the bursa reduced. Cuticle of the bursa extends forming a membrane between the dorsal lobe and the genital cone. Distal tip of the dorsal ray forms a spine. Well-developed genital cone. Spicules with well developed wings, 3 points at the distal tips. Female: Length of the body twice more than the male. Five to 7 tubercles or appendages at the posterior end.

Remarks. This species was described for the first time from the intestine of Carollia brevicauda (Schinz, 1821) and C. perspicillata captured in the towns of Samiria and the Yanacuya River, Iquitos, Peru; and Carollia castanea Allen, 1890, and C. perspicillata captured in San Pedro, Napo, Ecuador (Durette-Desset \& Vaucher 1989). The finding of C. touzeti parasitizing C. perspicillata is the first report of the occurrence of this host parasite association for the department of Junin, Peru.

Onchocercidae Leiper, 1911

Litomosoides Chandler, 1931

Litomosoides brasiliensis Almeida, 1936 (Fig. 2C-D)

Materials examined. Peru: Junin: Chanchamayo: La Merced, $11^{\circ} 04^{\prime} 12^{\prime}$ 'S, $75^{\circ} 20^{\prime} 37^{\prime \prime} \mathrm{W}$, 15-16.iv.2016, Minaya, D. (MUFV:ZOOHPIA:3); Peru: Junin: Chanchamayo: La Merced, $\quad 11^{\circ} 04^{\prime} 16$ "S, $\quad 75^{\circ} 20^{\prime} 36^{\prime \prime} \mathrm{W}, \quad 11-12$. vii.2016, Minaya, D. (MUFV:ZOO-HPIA:2); Peru: Junin: Chanchamayo: La Merced,

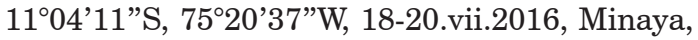
D. (MUSM-3595, MUFV:ZOO-HPIA:4); Peru:

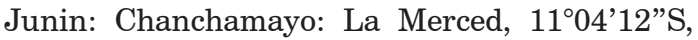
75²0'37'W, 7-8.vi.2016, Minaya, D. (MUSM3596, MUFV:ZOO-HPIA:5); Peru: Junin:

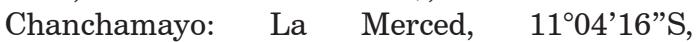
75²0'36"W, 11-12.vii.2016, Minaya, D. (MUSM3597, MUFV:ZOO-HPIA:6).

Hosts. Artibeus lituratus (1 evaluated, 1 infected), Peru: Junin: Chanchamayo: La Merced, 1104'12"S, 75²0'37"W, 21-26.v.2014, Guabloche A. (MUFV-ZOO5); A. planirostris (4 evaluated, 2 infected), Peru: Junin: Chanchamayo: La Merced,

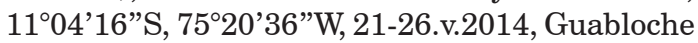
A. (MUFV-ZOO20); Carollia benkeithi (1 evaluated, 1 infected), Peru: Junin: Chanchamayo: 
Table 1. Endoparasitic helminths of bats from Chanchamayo, Junin, Peru. $\mathrm{N}=$ total number of parasites, $\mathrm{P} \%=$ prevalence, $\mathrm{n}=$ number of infected hosts/ number of total hosts, $\mathrm{MII}=$ mean infection intensity, MIA = mean infection abundance.

\begin{tabular}{|c|c|c|c|c|c|c|}
\hline Host & Helminths & Site of infection & $\mathrm{N}$ & $\mathrm{P} \%(\mathrm{n})$ & MII & MIA \\
\hline \multirow[t]{2}{*}{ Artibeus lituratus } & Anenterotrema iannaconei $(\mathrm{T})$ & Duodenum & 4 & $100(1 / 1)$ & 4 & 4 \\
\hline & Litomosoides brasiliensis $(\mathrm{N})$ & Mesentery & 2 & $100(1 / 1)$ & 2 & 2 \\
\hline \multirow[t]{2}{*}{ Artibeus planirostris } & Anenterotrema iannaconei $(\mathrm{T})$ & Duodenum & 2 & $25(1 / 4)$ & 2 & 0.5 \\
\hline & Litomosoides brasiliensis $(\mathrm{N})$ & Mesentery & 6 & $50(2 / 4)$ & 3 & 1.5 \\
\hline Carollia benkeithi & Litomosoides brasiliensis $(\mathrm{N})$ & Mesentery & 22 & $100(1 / 1)$ & 22 & 22 \\
\hline \multirow[t]{3}{*}{ Carollia perspicillata } & Anenterotrema iannaconei $(\mathrm{T})$ & Duodenum & 169 & $20(4 / 20)$ & 42.2 & 8.45 \\
\hline & Litomosoides brasiliensis $(\mathrm{N})$ & Mesentery & 52 & $50(10 / 20)$ & 5.2 & 2.6 \\
\hline & Carostrongylus touzeti $(\mathrm{N})$ & Intestine & 4 & $5(1 / 20)$ & 2 & 0.1 \\
\hline Glossophaga soricina & Litomosoides brasiliensis $(\mathrm{N})$ & Mesentery & 20 & $50(1 / 2)$ & 20 & 10 \\
\hline \multirow[t]{2}{*}{ Phyllostomus discolor } & Seuratum sp. (N) & Intestine & 11 & $50(1 / 2)$ & 11 & 5.5 \\
\hline & Atriotaenia hastati $(\mathrm{C})$ & Intestine & 28 & $50(1 / 2)$ & 28 & 14 \\
\hline
\end{tabular}
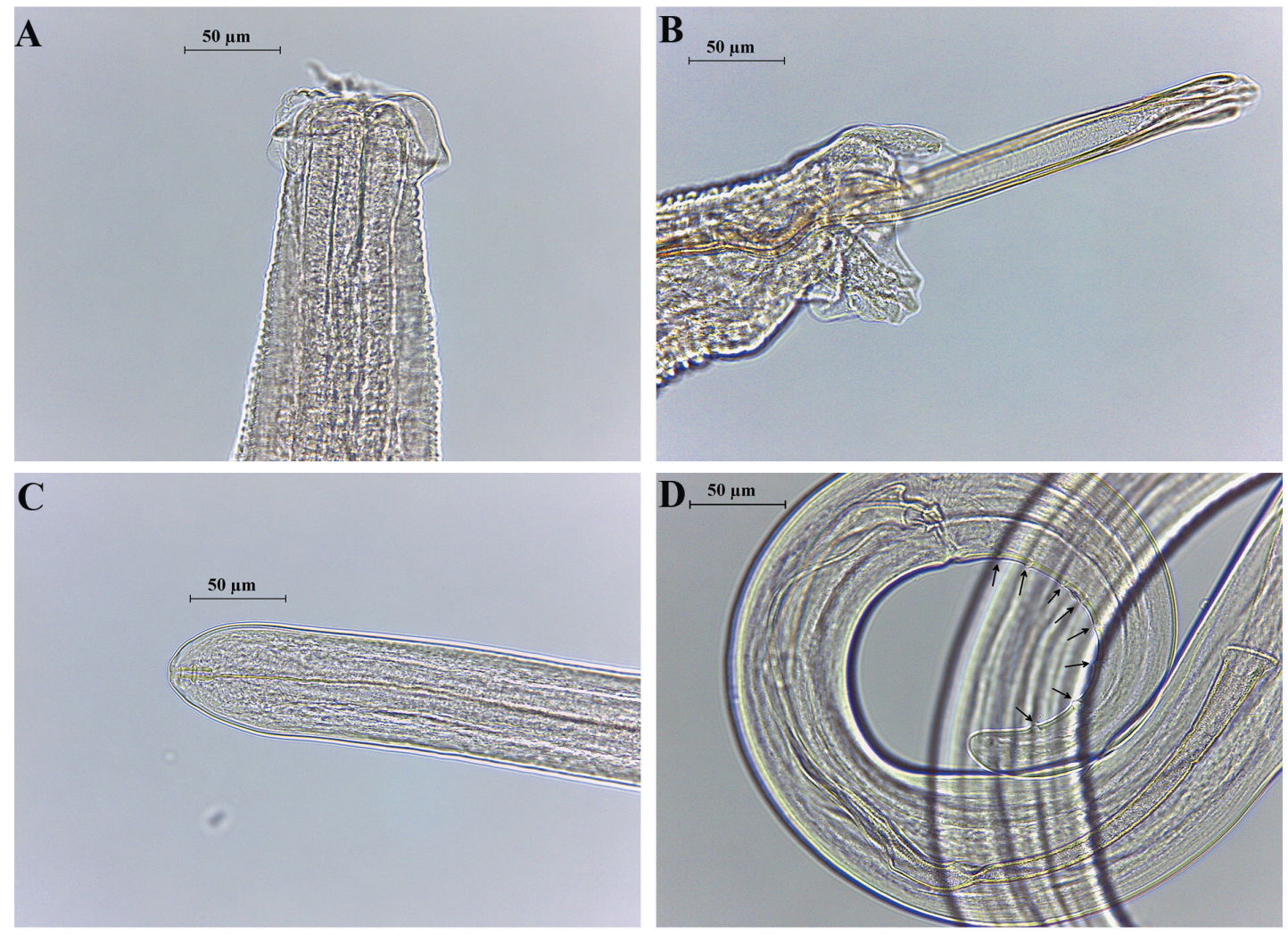

Fig. 2. Nematodes of bats (Chiroptera, Phyllostomidae) in the Department of Junin, Peru. A-B Carostrongylus touzeti from Carollia perspicillata. A. Anterior end of body. B. Male posterior end of body, spicules with well developed alae, and three points at the distal tips. C-D. Litomosoides brasiliensis from Carollia benkeithi. C. Anterior end of body, cuticular wall of the buccal capsule with two rings. D. Male posterior end of body, four pairs of post-cloacal papillae (arrows), two spicules of different lengths, the right one with triangular shape at the posterior end followed by a protrusion. 
La Merced, $11^{\circ} 04^{\prime} 11^{\prime \prime S}, \quad 75^{\circ} 20^{\prime} 37^{\prime \prime} \mathrm{W}, \quad 21-$ 26.v.2014, Guabloche A. (MUFV-ZOO10); C. perspicillata (20 evaluated, 10 infected), Peru:

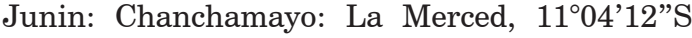
7520'37”W, 10-15.iv.2013, 21-26.v.2014, (MUFVZOO7); Glossophaga soricina (2 evaluated, 1 infected), Peru: Junin: Chanchamayo: La Merced,

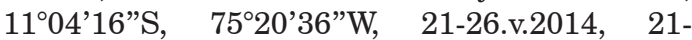
26.v.2014, (MUFV-ZOO14).

Site of infection. Thoracic and abdominal cavity.

Identification. Based on 18 individuals (7 male, 11 female). Two large latero-ventral cephalic papillae half the length of the buccal capsule, cuticular wall of the buccal capsule usually with 2 rings, 1 triangular in longitudinal section, the other smaller anterior, almost always visible. Male: 4 pairs of post-cloacal papillae, almost aligned in the midline, the anterior pair regularly away from the cloacal opening. Spiral tail with 2 chitinized unequal spicules, the smaller one with triangular shape at the posterior end followed by a protrusion. Female: The vagina usually subspherical but can also be elongated, the vulva is mostly located far behind the esophagus. Tail generally straight.

Remarks. This species was redescribed by Guerrero et al. (2002), based on material collected from Peru and French Guiana, who also describe the late larval stage of this species to understand the evolution of this genus with additional and more detailed data. It was reported for the first time for Peru by Guerrero et al. (2002) in the bats Anoura caudifer (Geoffroy, 1818), C. perspicillata and Sturnira lilium Geoffroy, 1810, from the towns of Camisea - Cusco and Paquitza - Manu National Park. In this study, L. brasiliensis is registered for the first time for the department of Junin.

Seuratidae Railliet, 1906

Seuratum Hall, 1916

Seuratum sp.

(Fig. 3A-B)

Materials examined. Peru: Junin: Chanchamayo: La Merced, $11^{\circ} 04^{\prime} 11^{\prime \prime S}, 75^{\circ} 20^{\prime} 37^{\prime}$ W, 11-12. vii.2016, Minaya, D. (MUSM-3598, MUFV:ZOOHPIA:7).

Host. Phyllostomus discolor (2 evaluated, 1 infected), Peru: Junin: Chanchamayo: La Merced,

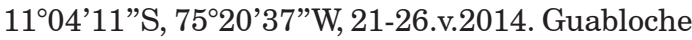
A (MUFV-ZOO13).

Site of infection. Small intestine.

Identification. Based on 4 individuals (4 fema- le). Female: cuticle support with twenty longitudinal crests; crests divided by transverse grooves. Long esophagus, with maximum width at the anterior end. Presence of nerve ring and cervical papillae at the anterior end. Vulva from the anterior end, marked by visible annular constriction and 2 pairs of sessile papillae located laterodorsal and lateroventrally. Amphidelphic uterus, thickwalled vagina, directed anteriorly. Eggs 29 to 33 $\mu \mathrm{m}$ long.

Remarks. Seuratum mucronatum (Rudolphi, 1809), Seuratum cancellatum Chitwood, 1938 and Seuratum congolense Sandground, 1937 are the only species of Seuratum recorded parasitizing bats, intermediate hosts are unknown in these parasites. In other Seuratum species that parasitize rodents, orthoptera and blatelides are recorded as intermediary hosts (Specian \& Ubelaker 1976). This genus is reported for the first time for Peru and for the host $P$. discolor. The genus Seuratum was listed by Fugassa (2015) for Argentina.

Trematoda

Anenterotrematidae Yamaguti, 1958

Anenterotrema Stunkard, 1938

Anenterotrema iannaconei Achatz, Cardenas-Callirgos, Tkach 2018

Materials examined. Peru: Junin: Chancha-

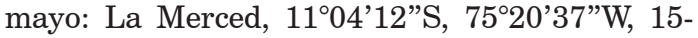
16.iv.2016, Minaya, D. (MUFV:ZOO-HPIA:9); Peru: Junin: Chanchamayo: La Merced,

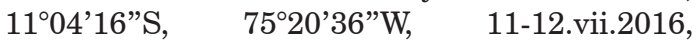
Minaya, D. (MUFV:ZOO-HPIA:10); Peru:

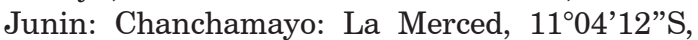
75²0'37'W, 7-8.vi.2016, Minaya, D. (MUFV:ZOOHPIA:11).

Hosts. Artibeus lituratus (1 evaluated, 1 infected), Peru: Junin: Chanchamayo: La Merced, 1104'12"S, 75²0'37"W, 21-26.v.2014. Guabloche A. (MUFV-ZOO5); A. planirostris (4 evaluated, 1 infected), Peru: Junin: Chanchamayo: La Merced,

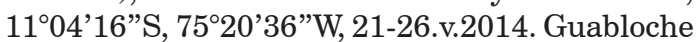
A. (MUFV-ZOO20); Carollia perspicillata (20 evaluated, 4 infected), Peru: Junin: Chanchamayo: La Merced, $11^{\circ} 04^{\prime} 12$ "S 75²0'37”W, 10-15.iv.2013, 21-26.v.2014. Guabloche A. (MUFV-ZOO7).

Site of infection. Duodenum.

Identification. Based on 10 individuals. Body fusiform, maximum width at level of ventral sucker. Tegument thin, unarmed. Oral sucker subspherical, subterminal, somewhat smaller than ventral sucker. Ventral sucker usually transversely oval. Pharynx, esophagus, and intestinal 

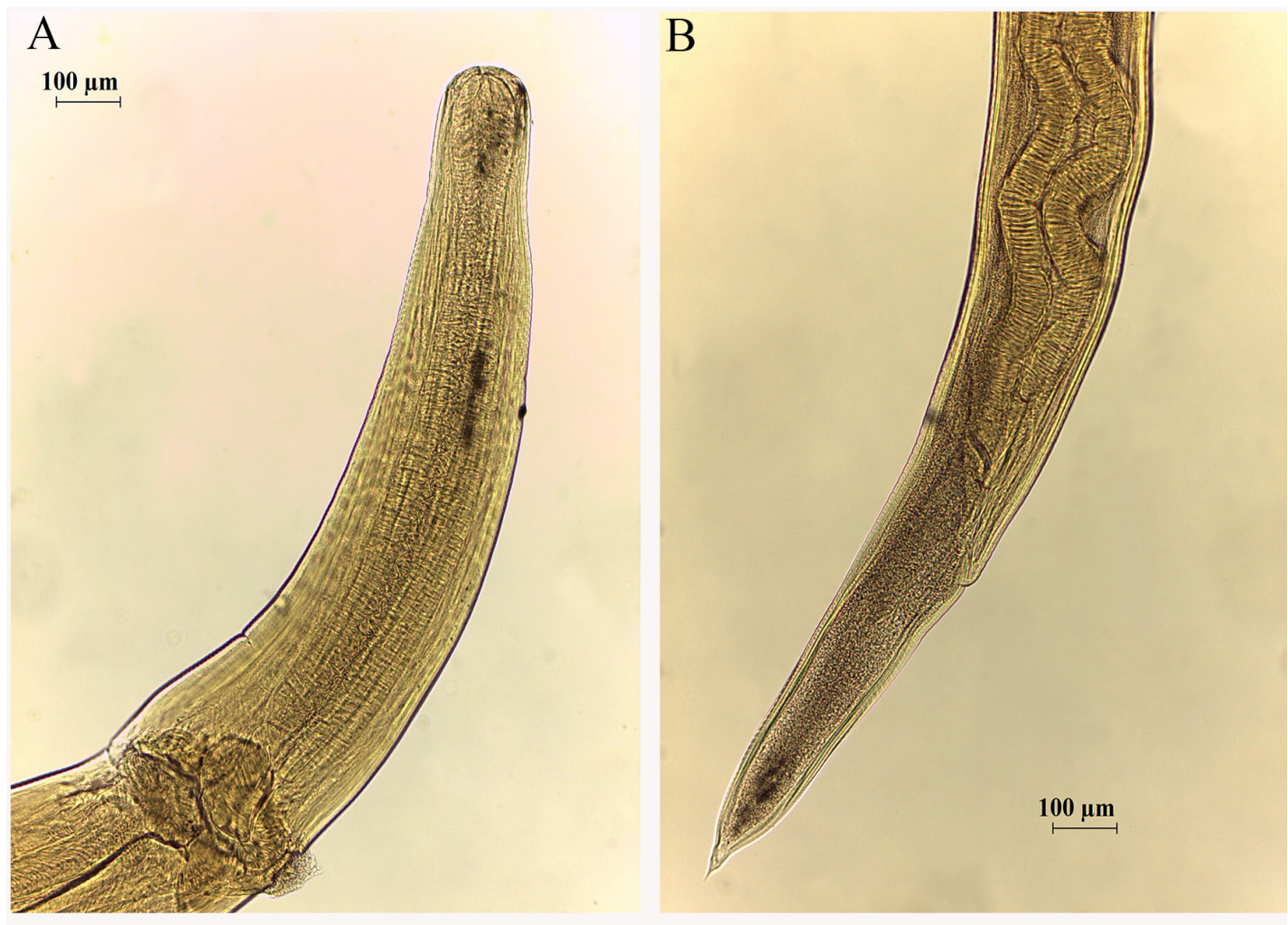

$\mathrm{C}$

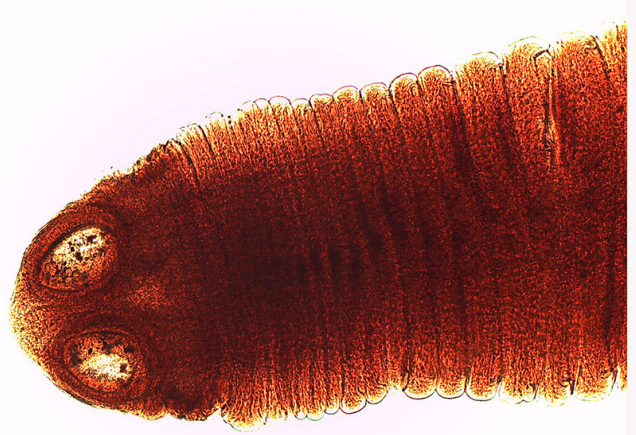

$\mathrm{D}$

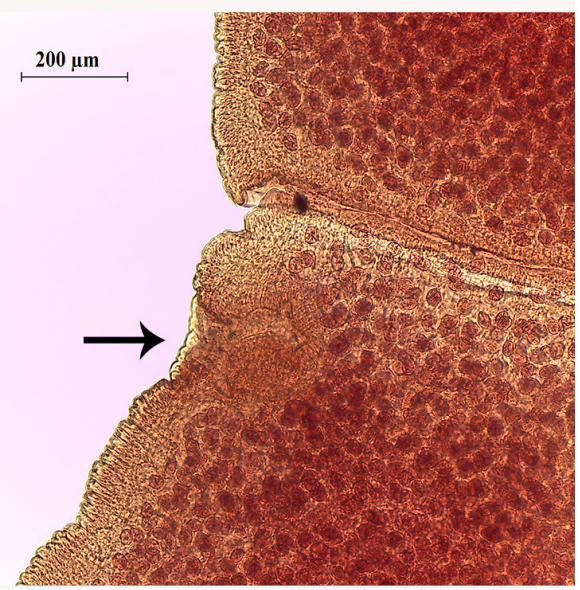

Fig. 3. Nematodes and cestodes of bats (Chiroptera, Phyllostomidae) in the Department of Junin, Peru. A-B. Seuratum sp. from Phyllostomus discolor. A. Anterior end of body. B. Posterior end of body. C-D. Atriotaenia hastati from Phyllostomus discolor. C. Scolex with four suckers without hooks or rostellum. D. Muscular and pronounced genital atrium (arrow).

ceca absent. Gonads primarily in middle third of body; occasionally ovary extends into posterior third of body. Testes usually opposite, rarely diagonal, subspherical to oval, located on either side of body approximately at level of posterior margin of ventral sucker. Cirrus sac thin-walled, oval to subspherical, anterior to and occasionally overlapping with ventral sucker. Cirrus sac contains coiled seminal vesicle and cirrus. Genital pore median at approximately third of distance between oral and ventral sucker. Ovary, usually smaller than testes, median or submedian, usually post testicular. Vitellarium consists of numerous follicles of varying shape and size, irre- 
gularly distributed posterior to gonads. Uterus strongly developed with numerous loops occupying posterior two thirds of body, occasionally extending slightly anterior to ventral sucker, usually overlapping gonads.

Remarks. The genus Anenterotrema parasitizes exclusively neotropical bats. Currently there are six species and the last of them, Anenterotrema iannaconei, was discovered by Achatz et al. (2018) from the duodenum of Carollia brevicauda Schinz, 1821 collected from the locality of Tingo María, province of Huánuco, Peru; and was the first record of this genus in Peru. Anenterotrema iannaconei differs from the other species in having smaller eggs, lack of a transverse fold in the anterior end of the body, a much larger cirrus sac, by its relatively smaller oral suckerin comparison to ventral sucker, and the ovary is almost immediately postacetabular and anterior to almost all vitelline follicles (Achatz et al., 2018).

\section{Cestoda}

Anoplocephalidae Cholodkovsky, 1902

Atriotaenia Sandground, 1926

Atriotaenia hastati Vaucher, 1982

(Fig. 3C-D)

Materials examined. Peru: Junin: Chanchamayo: La Merced, $11^{\circ} 04^{\prime} 11^{\prime \prime S}, 75^{\circ} 20^{\prime} 37^{\prime} \mathrm{W}, 11-12$. vii.2016, Minaya, D. (MUSM-3598, MUFV:ZOOHPIA:8).

Host. Phyllostomus discolor (2 evaluated, 1 infected), Peru: Junin: Chanchamayo: La Merced, 11'04'11”S, 75²0'37”W, 21-26.v.2014. Guabloche A (MUFV-ZOO13).

Site of infection. Small intestine

Identification. Based on 5 individuals. Cestodes of small size, scolex with 4 suckers without hooks or rostellum. Proglottids slightly craspedote, mature from 4 to 6 , gravid from 3 to 4 ; each proglottid with a set of reproductive organs, the genital pores alternating irregularly. Muscular and pronounced genital atrium. Number of testicles in mature proglottids is 50 to 60 , grouped bordering the posterior side of the ovary. Cirrus without spines opens at the base of the atrium. Beneath the sac of the cirrus runs through the vagina which is surrounded by a dense layer of cells. The seminal receptacle is lobed and is located behind the ovary. Ovary with 2 lobed wings. Uterus difficult to distinguish.

Remarks. This genus was created from samples collected from the Nasua nasua (Linneaeus, 1766) ring-tailed coati. Atriotaenia hastati was first described by Vaucher (1982a) from the bat Phyllostomus hastatus (Pallas, 1767), collected in Paraguay. In Peru it was recorded for the first time by Vargas et al. (2009a) for the same host collected in the Cerros de Amotape National Park, Tumbes. We registered $P$. discolor as a new host for A. hastati.

\section{DISCUSSION}

The diversity of Neotropical bats is 390 species in 99 genera (Solari \& Martínez-Arias, 2014). The diversity of mammals reported for Peru is 467 species, making Peru the country with the third greatest diversity of species in the Americas and the fifth in the world (Pacheco et al., 2009; Quintana et al., 2009). Of this diversity reported for Peru, 172 are species of the order Chiroptera, the group of mammals with the greatest diversity (Díaz et al., 2016). Bats occupy several levels in the food chain, which adds to their diversity and makes them important regulators of complex ecological processes in tropical forests (Ochoa, 1992; Reis et al., 2013; Walldorf \& Mehlhorn, 2014).

In the evaluation of the bats from Junin, conducted in this study, it has been observed that 5 out of 6 species of bats evaluated were parasitized by the nematode $L$. brasiliensis, which registers a wide range of hosts only in South America (Santos \& Gibson, 2015). The high prevalence of L. brasiliensis as observed in Table 1 is probably due to the life cycle of this nematode, which uses different hematophagous arthropods (e.g., ticks, mites, mosquitoes, batflies, bugs) as intermediate hosts, as suggested by Scott et al. (1951) and Santos \& Gibson (2015). Life cycle studies have been carried out on Litomosoides species that parasitize field rodents and it has been found that species of ticks, mosquitoes and bed bugs can act as vectors for this parasite (Williams, 1948). We suggest that the success of parasites transmitted by vectors (hematophagous arthropods) is greater than that of those transmitted by intermediate hosts (eaten by the final host), because one or more intermediate hosts infect a single host individual, while a single vector has the potential to transmit the parasite to several final hosts by means of a mechanism of micropredation of the vector to the host (Wilson et al., 2017). Likewise this genus of nematode, Litomosoides, together with Litomosa Yorke \& Maplestone, 1926, are the most well-known nematode genera that parasitize bats (Ramasindrazana et al., 2016). Based on the list presented in this study, only the genus 
Litomosoides is registered for Peru and based on the records presented by Santos \& Gibson (2015) also only for South America. Guerrero \& Bain (2011) considered that L. brasiliensis, as generally regarded, may represent a complex of species, and not just a single taxonomic entity.

The parasitism by Litomosoides species in A. planirostris has been reported in bats of South America, being L. chandleri Esslinger, 1973 the only species registered up to now in A. planirostris (Santos \& Gibson, 2015). In our study, we reported this bat as a new host for L. brasiliensis.

Is important to indicate that 2 species of nematodes have been registered in A. lituratus in South America: Bidigiticauda vivipara Chitwood, 1938 and Cheiropteronema globocephala Sandground, 1929 (Guerrero, 1985; Durette-Desset \& Vaucher, 1988). In our study only 1 individual was evaluated of $A$. lituratus which was found parasitized by the nematode $L$. brasiliensis, this being the first record of the genus Litomosoides for this host. It is likely that increasing the size of the sample to be evaluated in this species of bat in Peru, also increases the report of more species of parasites, because $A$. $l i$ turatus has registered 6 species of helminths in South America (Santos \& Gibson, 2015).

In relation to the bat $C$. benkeithi, this species is relatively new, was described and separated from $C$. castanea and C. brevicauda by Solari \& Baker (2006). Being a relatively new species, no parasitic records were found in this bat, this study is the first to provide information about the helminths associated with $C$. benkeithi.

In this study it was observed that nematodes had the highest prevalence of infection with $56.7 \%$ (17 of 30) of hosts parasitized. This higher prevalence of nematodes in Chiropteran hosts was observed by Cardia (2012) in a study of bat helminths from the Central-West region of the State of Sao Paulo, Brazil. Cardia (2012) indicated that $30.5 \%$ of the hosts infected by helminths were exclusively with nematodes. In our study, nematodes were the largest parasitic component found in the bats evaluated, and likewise the group with the greatest diversity of species, suggesting that nematodes can coexist and develop successfully in the presence of other helminths and that, in turn, it would not be competent for the development of other helminths.

The largest number of parasites observed was the trematode Anenterotrema iannaconei. High number of trematodes were also observed in bats from the valleys of Aburrá, Colombia (Castiblanco \& Vélez, 1982). These authors sug- gest that the high number may be due to the feeding heterogeneity of the bats, which include insects, which may present immature forms of trematodes (McAllister et al., 2007). We found low prevalences of $A$. iannaconei, even though this factor is strongly affected by the behavior and feeding strategies of the bats (Coggins, 1988).

In our study, only 1 individual was observed parasitized with a species of cestode; this low occurrence of parasitism by tapeworm species was also noted by Vargas et al. (2009a), who recorded 2 species of cestodes from 39 bats collected in Amotape, Tumbes, Peru. In the same way, Nogueira et al. (2004) found only 1 species of cestode Vampirolepis elongatus (Rego, 1962) in the bat Platyrrhinus helleri (Peters, 1866), collected in the Amazon of Brazil.

All the parasites mentioned in the description are new records for the department of Junin, Peru. We also added Peru as the new geographic registry for a species of Seuratum. Phyllostomus discolor is also registered as a new host of the nematode Seuratum sp. and of the cestode A. hastati. Artibeus lituratus and A. planirostris are new hosts for the trematode A. iannaconei. Bats A. lituratus, A. planirostris and $C$. benkeithi are also new host records for the nematode $L$. brasiliensis.

\section{List of parasite helminths of bats in Peru}

Santos \& Gibson (2015) presented a list of parasitic helminths of bats in South America. According to this list, 14 parasitic helminth species have been recorded from bats in Peru. In the present work we update this information and increase the list of parasite helminths of bats to 26 species, an increase of $185.7 \%$.

Twenty-six species of helminths were recorded among trematodes, cestodes and nematodes, of which 21 were identified at the species level, 5 were identified at generic level (Table 2 ). The nematode $L$. brasiliensis was recorded from 7 chiropteran hosts and is the helminth with the highest number of bat hosts. Twenty-two bat species had at least one parasitic infection, representing 4 families and 15 genera. The bats A. planirostris and $P$. hastatus have the highest number of parasitic records in Peru with 7 species of helminths each one, followed by $C$. perspicillata with 4 species, and A. lituratus, P. discolor and T. brasiliensis with 3 species each (Table 3). Among the 24 departments of Peru, ten recorded at least one study about parasites of Chiroptera, and the department of Loreto has the largest number of parasitological studies from this group of mam- 
Table 2. List of parasitic helminths registered in bats from Peru: hosts, geographical distribution and references.

\begin{tabular}{llll}
\hline Helminth & Host(s) & $\begin{array}{l}\text { Site of in- } \\
\text { fection }\end{array}$ & Locality References \\
\hline
\end{tabular}

Phylum PLATYHELMINTHES

Class RHABDITOPHORA

Order TREMATODA

\section{Anenterotrematidae Yamaguti,} 1958

Anenterotrema iannaconei Achatz, Cardenas-Callirgos \& Tkach, 2018

Edcaballerotrema sp.)

\begin{abstract}
Artibeus lituratus
\end{abstract}
Artibeus planirostris

Carollia brevicauda

Carollia perspicillata

Carollia perspicillata

Phyllostomus hastatus

\section{Diplostomidae Poirier, 1886}

Neodiplostomum vaucheri Dubois, Chrotopterus auritus 1983

\section{Lecithodendriidae Lühe, 1901}

Ochoterenatrema fraternum

Freitas \& Ibañez, 1963

Tadarida brasiliensis

Stomach, Intestine

Tadarida brasiliensis

Paralecithodendrium navicu-

lum (Macy, 1936) (Syn

Prosthodendrium scabrum)

\section{Stomylotrematidae Poche,} 1926

Stomylotrema sp.

Phyllostomus hastatus Intestine

Order CESTODA

Anoplocephalidae

\section{Cholodkovsky, 1902}

Atriotaenia hastati Vaucher, 1982

Phyllostomus hastatus

Hymenolepididae Ariola, 1899

Vampirolepis elongatus

Artibeus planirostris

Vampirolepis mazanensis (Vaucher, Saccopteryx bilineata 1986)

Vampirolepis phyllostomi (Vaucher, Phyllostomus hastatus 1982)

Vampirolepis artibei Zdzitowiecki Glossophaga soricina \& Rutkowska, 1980

Vampirolepis sp
Rynchonycteris naso

Duodenum Junín present study

Duodenum Junín present study

Intestine Huánuco Achatz et al. (2018)

Duodenum Junín present study

Intestine Amazonas Ibañez et al. (2005)

Intestine Amazonas Ibañez et al. (2005)

Intestine Loreto Dubois (1983)

La Libertad Freitas \& Ibañez (1963), Tantalean et al. (1992)

Stomach, Lima Tantalean et al. Intestine (1992)

Amazonas Ibañez et al. (2005)

Tumbes Vargas et al. (2009b)

Junín present study

Intestine Loreto Vaucher (1982b)

Intestine Loreto Vaucher (1982b)

Intestine Loreto Vaucher (1986)

Intestine Loreto Vaucher (1986)

Intestine Loreto Vaucher (1982b)

Unknown Ica $\quad$ Mendoza et al. (1997)

Artibeus fraterculus Intestine Amazonas Ibañez et al. (2005)

Noctilio leporinus Intestine Tumbes Vargas et al. (2009b)

Phyllostomus hastatus Intestine Amazonas Ibañez et al. (2005) 
Table 2. (Cont.)

\section{Phylum NEMATODA \\ Superfamily \\ TRICHOSTRONGYLOIDEA \\ Ornithostrongylidae \\ (Travassos, 1937)}

Allintoshius parallintoshius

(Araujo, 1940)

Myotis nigricans Intestine Loreto

Molineidae Durette-Desset \&

Chabaud, 1977

Biacantha desmoda Wolfgang, 1954

Bidigiticauda vivipara Chitwood, 1938

Carostrongylus touzeti Durette-

Desset \& Vaucher, 1989

Cheiropteronema globocephala

(Sandground, 1929)

Cheiropteronema sp.

Histiostrongylus spineus Vaucher \& Durette-Desset 1999

Parahistiostrongylus octacanthus Lent \& Freitas, 1940

Tricholeiperia peruensis Vargas, Martínez \& Tantaleán, 2009

Superfamily FILARIOIDEA

\section{Onchocercidae Leiper, 1911}

Litomosoides brasiliensis Almeida, Anoura caudifer 1936

Litomosoides chandleri Esslinger,
1973
Litomosoides solarii Guerrero,
Martin, Gardner \& Bain, 2002
Tadaridanema delica-
tus (Schwartz, 1927) (Syn.
Molinostrongylus delicatus)
Superfamily SEURATOIDEA

Mesentery Cusco

Mesentery Junín

Artibeus lituratus

Artibeus planirostris

Carollia benkeithi

Mesentery

Mesentery

Carollia perspicillata,

Glossophaga soricina

Sturnira lilium

Artibeus planirostris

Trachops cirrhosus

Tadarida brasiliensis

Mesentery

Mesentery

Mesentery

Mesentery

Mesentery

Intestine
Ica

Loreto

Loreto

Junín

Loreto

Loreto

Loreto

Loreto

Loreto

Loreto

Tumbes
Rossi \& Vaucher (2002)

Tantalean (2016)

Tantalean (2016)

Durette-Desset \& Vaucher (1989) present study

Durette-Desset \& Vaucher (1988)

Durette-Desset \& Vaucher (1988)

Durette-Desset \& Vaucher (1988)

Vaucher \& DuretteDesset (1999)

Vaucher \& DuretteDesset (1999)

Vaucher \& DuretteDesset (1999)

Vargas et al. (2009a)

\section{Seuratidae Hall, 1916}


mals (Table 2). According to the trophic guild of the bat hosts, the highest percentages $18.18 \%$ $(\mathrm{n}=4)$ was for Low-flying frugivore (LFF) and High-flying frugivore (HFF) among the 9 categories trophics (Table 3 ).

The information reviewed in this research was carried out until December 2018. This does not mean that from 2015 to 2018 there have been 12 more species registered for Peru; on the contrary, there was only one related study of bat helminths in Peru since the year 2008 which was carried out by Vargas et al. (2009ab). It is probable that the oversight of $185.7 \%$ of the available information, and possibly why it was not included in the list of Santos \& Gibson, is related to access to other studies. This type of information is described by Oliva \& Luque (2010) as "gray information", which raises the question of if "... there is a gray information not accessible in the databases and that normally corresponds to local journals, records presented at conferences, thesis of pre-post degree and / or technical reports? “(p.102). In the preparation of this updated list of bat helminths in Peru we have not included the abstracts of conferences or theses, but if we had access to information from local scientific journals that do not have a virtual version, then they were included (Martín-Martín et al., 2018).

In the elaboration of this updated list we have included information on trophic guild, i.e., the habit and feeding strategy of the hosts, because little is known about the life cycles of parasitic helminths in this group of mammals (Coggins, 1988) and we believe that additional knowledge about the feeding ecology of bats can provide important insights into the relationships between these groups, as suggested by Ubelaker (1970) and Reis et al. (2013). The diet is important to explain parasitism of helminths in bats, because many of their diet components such as arthropods, molluscs and small vertebrates are involved in the development of the helminth biological cycle, acting as intermediate or paratenic hosts (Esteban et al., 1991; McAllister et $a l ., 2007)$. But not only the diet can influence the parasitism, but also the corporal size and geographical distribution of the bats, because these factors promote the colonization of new species and would be associated with a high diversity of parasites (De Albuquerque et al., 2016). It is thus that the larger bats would be expected to harbor the richer parasite assemblages, since they provide a greater spatial variety for niche diversification (Morand \& Harvey, 2000; Vitone et al., 2004; Milano, 2016). This could explain why $A$. planirostris and $P$. hastatus, which have a larger body size (above $90 \mathrm{~mm}$ ), had greater helminth richness than $C$. perspicillata, which has a smaller body size (below $65 \mathrm{~mm}$ ) (Reis et al., 2013).

In the development of the review, it has been observed that several fruit or nectivorous bats have reported cestode parasitism. This could be explained by the fact that there are species such as Glossophaga soricina (Pallas, 1766), known to be nectivorous, which presents flexibility in its diet extending to insects such as beetles (Coleoptera), flies (Diptera) and moths (Lepidoptera) (Clare et al., 2014).

Also, a greater geographic range of bats could accommodate a greater diversity of parasites, because their distribution would be shared with other bats, allowing the acquisition of other parasitic species (Krasnov et al., 2004; Milano, 2016). That is, in a smaller geographic space and short periods of time, the coexistence between host species can facilitate the transfer of parasites and increase the richness of parasite species in the communities protected by the individual host species and in a larger geographic space, the host species with wide geographical distributions will overlap with those of other host species from which they can acquire new parasites on a longer time scale (Milano, 2016). It is to be expected then, that host species with broader geographical distributions have higher species richness than those with more restricted distributions (Poulin \& Morand, 2004). The 6 bats surveyed in Junin, Peru have wide distribution in all South American (Reis et al., 2013).

In the developed list we have found that $A$. planirostris and P. hastatus are the bats with the highest records of parasitic helminths in Peru. In the case of $A$. planirostris, in spite of being a species with a diet based on fruits and of which it would be expected less records of helminth parasites, it turned out to have greater parasitic diversity than $P$. hastatus, which is an omnivore species. Although the diet of A. planirostris is predominantly of fruits (80\%), some individuals of this species consume arthropods, including beetles (Coleoptera), dipterans and accidentally at the time of ingestion of the fruits, hymenoptera (ants) and mites (Hollis, 2005). Likewise, both species are known to have wider geographic distribution than other species of their respective genus (Gardner, 2007; Díaz et al., 2016), which would explain, along with the information on their feeding habits, why both species of bats are the most for parasitized by helminths. 
Table 3. Host-Parasite List. $\dagger$ Present study. Low-flying insectivore $=$ LFI. High-flying insectivore $=$ HFI. Insectivore-piscivore = IPI. Omnivore-nectivorous = OMN. High-flying frugivore = HFF. Lowflying frugivore $=$ LFF. Insectivore-carnivore $=$ INC. Hematophagous $=$ HEM. Omnivore-predator $=$ OMP.

\begin{tabular}{l} 
Host \\
\hline EMBALLONURIDAE \\
Rhynchonycteris naso (Wied-Neuwied, \\
1820) \\
Saccopteryx bilineata (Temminck, 1838) \\
MOLOSSIDAE \\
Tadarida brasiliensis (I. Geoffroy, 1824)
\end{tabular}

\section{NOCTILIONIDAE}

Noctilio leporinus (Linnaeus, 1758)

\section{PHYLLOSTOMIDAE}

Anoura caudifer (E. Geoffroy, 1818) Artibeus fraterculus Anthony, 1924 Artibeus lituratus (Olfers, 1818)

Artibeus obscurus (Schinz, 1821) Artibeus planirostris (Spix, 1823)

Carollia benkeithi Solari \& Baker, 2006 Carollia brevicauda (Schinz, 1821)

Carollia perspicillata (Linnaeus, 1758)

Chrotopterus auritus (Peters, 1856)

Desmodus rotundus (É. Geoffroy, 1810)

Glossophaga soricina (Pallas, 1766)

Lophostoma silvicolum d'Orbigny, 1836

Phyllostomus discolor Wagner, 1843
Trophic
guild Parasite

LFI Vampirolepis mazanensis

Cestoda

LFI Vampirolepis mazanensis

Cestoda

HFI

Ochoterenatrema fraternum

Paralecithodendrium naviculum

Tadaridanema delicatus

IPI Vampirolepis sp.

Cestoda

OMN Litomosoides brasiliensis Nematoda

HFF Vampirolepis sp. Cestoda

HFF Cheiropteronema globocephala Nematoda

Litomosoides brasiliensis $\dagger$

Anenterotrema iannaconei $\dagger$

HFF Vampirolepis elongatus

$\mathrm{HFF}$ Anenterotrema iannaconei $\dagger$

Vampirolepis elongatus

Bidigiticauda vivipara

Cheiropteronema globocephala

Cheiropteronema sp.

Litomosoides brasiliensis $\dagger$

Nematoda

Trematoda

Cestoda

Trematoda

Cestoda

Nematoda

Nematoda

Nematoda

Nematoda

Litomosoides chandleri

Nematoda

LFF Litomosoides brasiliensis $\dagger$

Nematoda

LFF Anenterotrema iannaconei

Trematoda

Carostrongylus touzeti

Nematoda

LFF Anenterotrema sp. (=Edcaballerotrema sp.) Trematoda Anenterotrema iannaconei $\dagger \quad$ Trematoda

Carostrongylus touzeti

Nematoda

Litomosoides brasiliensis

Nematoda

INC Neodiplostomum vaucheri

Trematoda

HEM Biacantha desmoda

Nematoda

OMN Vampirolepis artibei

Cestoda

Litomosoides brasiliensis $\dagger$

Nematoda

INC Tricholeiperia peruensis

Nematoda

OMP Atriotaenia hastati $\dagger$

Cestoda

Seuratum sp. $\dagger$

Nematoda

Histiostrongylus spineus 
Table 3. (Cont.)

\begin{tabular}{|c|c|c|c|}
\hline $\begin{array}{l}\text { Phyllostomus elongatus (E.Geoffroy, } \\
\text { 1810) }\end{array}$ & OMP & Parahistiostrongylus octacanthus & Nematoda \\
\hline \multirow[t]{7}{*}{ Phyllostomus hastatus (Pallas, 1767) } & OMP & Anenterotrema sp. (=Edcaballerotrema sp.) & Trematoda \\
\hline & & Stomylotrema sp. & Trematoda \\
\hline & & Atriotaenia hastati & Cestoda \\
\hline & & Vampirolepis phyllostomi & Cestoda \\
\hline & & Vampirolepis sp. & Cestoda \\
\hline & & Parahistiostrongylus octacanthus & Nematoda \\
\hline & & Seuratum sp. & Nematoda \\
\hline Sturnira lilium (E. Geoffroy, 1810) & LFF & Litomosoides brasiliensis & Nematoda \\
\hline Trachops cirrhosus (Spix, 1823) & INC & Litomosoides solarii & Nematoda \\
\hline Myotis nigricans (Schinz, 1821) & LFI & Allintoshius parallintoshius & Nematoda \\
\hline
\end{tabular}

Our results show that it is still necessary to increase the number of collections for the search of helminths in bats in Peru. Only 22 species of bats $(12.79 \%)$ have at least one parasite helminth record of a total diversity of 172 species of Chiroptera in the Peruvian territory.

\section{ACKNOWLEDGEMENTS}

We thank to Angelica Guabloche Zuñiga for the collaboration in the collection of bats in the field. We extend our thanks to Brenton Ladd for his comments to improve this manuscript.

\section{BIBLIOGRAPHY}

Achatz, T.J., J.M. Cardenas-Callirgos \& V.V. Tkach. 2018. New Anenterotrema Stunkard, 1938 (Digenea: Anenterotrematidae) from Silky ShortTailed Bat, Carollia brevicauda Schinz, 1821, in Peru. Comparative Parasitology 85: 78-82.

APA (American Psychological Association). 2012. Guidelines for ethical conduct in the care and use of nonhuman animals in research. American Psychological Association Committee on Animal Research and Ethics in 2010-11. American Psychological Association. Washington, 9 pp.

Bautista-Hernández, C.E., S. Monks, G. Pulido-Flores \& A.E. Rodríguez-Ibarra. 2015. Revisión bibliográfica de algunos términos ecológicos usados en parasitología, y su aplicación en estudios de caso. Estudios en Biodiversidad 1:11-19.

Bray, R.A., D.I. Gibson \& A. Jones. 2008. Key to the Trematoda. Volume 3. CABI, London, 799 pp.

Bush, A.O., K.D. Lafferty, J.M. Lotz \& A.W. Shostak. 1997. Parasitology meets ecology on terms: Margolis et al. revisited. The Journal of Parasitology 8: 575583.

Castiblanco, F. \& I. Vélez. 1982. Observación de tremátodos digenéticos en murciélagos del Valle de Aburrá y alrededores. Actualidades biológicas
11(42): 129-141.

Cardia, D.F. 2012. Helmintos de quirópteros da Região Centro-Oeste do Estado de São Paulo. PhD Tese. Universidade Estadual Paulista, Sao Paulo, 87 pp.

Clare, E.L., Goerlitz, H.R., Drapeau, V.A., Holderied, M.W., Adams, A.M., Nagel, J., Dumont, E.R., Hebert, P.D. \& Brock Fenton, M. 2014. Trophic niche flexibility in Glossophaga soricina: how a nectar seeker sneaks an insect snack. Functional Ecology 28(3): 632-641.

Coggins, J.R. 1988. Methods for the ecological study of bat endoparasites. In: T.H. Kunz (Ed), Ecological and behavioral methods for the study of bats, pp 475-489, Smithsonian Institution, Washington, DC.

Costello, M., K.H. Beard, R.T. Corlett, G. Cumming, V. Devictor, R. Loyola, B. Maas, A.J. Miller-Rushing, R. Pakeman \& R.B. Primack. 2016. Field work ethics in biological research. Biological Conservation 203: 268-271.

Cuartas-Calle, C. \& J. Muñoz-Arango. 1999. Nematodos en la cavidad abdominal y el tracto digestivo de algunos murciélagos colombianos. Caldasia 21: 10-25.

Datzmann, T., O. von Helversen \& F. Mayer. 2010. Evolution of nectarivory in phyllostomid bats (Phyllostomidae Gray, 1825, Chiroptera: Mammalia). BMC Evolutionary Biology 10: 165.

De Albuquerque, A.C.A., M.F.D. Moraes, A.C. Silva, I.M. Lapera, J.H. Tebaldi \& E.G.L. Hoppe. 2016. Helminth fauna of chiropterans in Amazonia: biological interactions between parasite and host. Parasitology research, 115: 3229-3237.

Díaz, M.M., L.F. Aguirre \& R.M. Barquez. 2011. Clave de identificación de los murciélagos del cono sur de Sudamérica. Centro de Estudios en Biología Teórica y Aplicada. Cochabamba, Bolivia, 94 pp.

Díaz, M.M., S. Solari, L.F. Aguirre, L.M. Aguiar \& R.M. Barquez. 2016. Clave de identificación de los murciélagos de Sudamérica. Publicación Especial $N^{\circ}$ 2. PCMA (Programa de Conservación de los Murciélagos de Argentina), 160 pp.

Dick, C.W. 2007. High host specificity of obligate ecto- 
parasites. Ecological Entomology 32: 446-450.

Dubois, G. 1983. Un Néodiplostome péruvien, Neodiplostomun $(N$.$) vaucheri n. sp. (Trematoda:$ Strigeoidea: Diplostomidae), parasite d'une Chauve-souris. Revue suisse de Zoologie 90: 179182.

Durette-Desset, M.C. \& C. Vaucher. 1988. Trichostrongyloidea (Nematoda) parasites de Chiroptères néotropicaux. II. Nouvelles données sur le genre Cheiropteronema Sandground, 1929. Revue suisse de Zoologie 95: 889-899.

Durette-Desset, M.C. \& C. Vaucher. 1989. Trichostrongyloidea (Nematoda) parasites de Chiroptères néotropicaux. III. Carostrongylus touzeti gen. n., sp. n. chez Carollia spp. (Phyllostomatidae). Revue suisse de Zoologie 96: 697-706.

Eisenberg, J.F. \& K.H. Redford. 2000. Mammals of the Neotropics. The central Neotropics. Vol 3: Ecuador, Perú, Bolivia, Brazil. University of Chicago Press, Chicago, 610 pp.

Esteban, J.G., J.L. Oltra-Ferrero, P. Botella \& S. MasComa. 1991. Helmintos de quirópteros en España: espectro faunístico e interés aplicado de su estudio. In: J. Benzal, O. De Paz (eds.), Los murciélagos de España y Portugal. Colección técnica, Ministerio de Agricultura, Pesca y Alimentación, pp. 282-304, Instituto Nacional para la Conservación de la Naturaleza, Madrid.

Falconaro, A.C., R.M. Vega \& G.P. Viozzi. 2018. Helminth communities of two populations of Myotis chiloensis (Chiroptera: Vespertilionidae) from Argentinean Patagonia. International Journal for Parasitology: Parasites and Wildlife 7: 27-33.

Fernandes, B.M., M.C. Justo, M.Q. Cárdenas \& S. Cohen. 2015. South American trematodes parasites of birds and mammals. Fiocruz, Rio de Janeiro, $551 \mathrm{pp}$.

Frank, R., J. Münster, J. Schulze, A. Liston \& S. Klimpel. 2014. Macroparasites of Microchiroptera: bat ectoparasites of Central and South America. In: S. Klimpel, H. Mehlhorn (eds.), Bats (Chiroptera) as vectors of diseases and parasites, pp 87-130. Springer-Verlag, Berlin, Heidelberg.

Freitas, J.F. \& H.N. Ibañez. 1963. Fauna Helmintológica do Perú. "Ochoterenatrema fraternum" sp. n. (Trematoda, Lecithodendriidae). Revista Brasileira de Biologia 23: 255-258.

Fugassa, M.H. 2015. Checklist of helminths found in Patagonian wild mammals. Zootaxa 4012: 271328.

Gardner, A.L. 2007. Mammals of South America. Volume 1: Marsupials, Xenarthrans, Shrews, and Bats. University of Chicago Press, Chicago, 669 pp.

Gregory, R.D., A.E. Keymer \& P.H. Harvey. 1996. Helminth parasite richness among vertebrates. Biodiversity and Conservation 5: 985-997.

Guerrero, R. 1985. Parasitología. In: M. Aguilera (ed.), El Estudio de los Mamíferos en Venezuela. Evaluación y Perspectivas, pp 35-91. Fondo Editorial Acta Científica Venezolana, Caracas,
Venezuela.

Guerrero, R., Martin C, S. Gardner \& O. Bain. 2002. New and known species of Litomosoides (Nematoda: Filarioidea): Important adult and larval characters and taxonomic changes. Comparative Parasitology 69: $177-195$.

Guerrero, R. \& O. Bain. 2011. Study of types of some species of "Filaria" (Nematoda) parasites of small mammals described by Von Linstow and Molin. Parasite 18:151-161.

Hill, J.E. \& J.D. Smith. 1984. Bats: a natural history. Austin: University of Texas Press. http://www. ucmp.berkeley.edu/mammal/eutheria/chirolh. html. Accessed on: 2017-4-25

Hollis, L. 2005. Artibeus planirostris. Mammalian Species, The American Society of Mammalogists. $1-6$.

Ibáñez, C. 1981. Biología y ecología de los murciélagos del Hato" El Frío" Apure, Venezuela. Estación Biológica de Doñana, Sevilla, 280 pp.

Ibáñez, N.H., C.C. Jara \& A.M. Guerra. 2005. Helmintos parásitos de mamíferos silvestres de Condorcanqui, Amazonas-Perú. Rebiol 25: 43-48.

Jones, K., A. Purvis \& J. Gittleman. 2003. Biological correlates of extinction risk in bats. American Naturalist 161: 601-614.

Kasso, M. \& M. Balakrishnan. 2013. Ecological and Economic Importance of Bats (Order Chiroptera). ISRN Biodiversity 2013: Article ID 187415.

Khalil, L.F., A. Jones \& R.A. Bray. 1994. Keys to the cestode parasites of vertebrates. $\mathrm{CAB}$ international, Albans, 746 pp.

Krasnov, B.R., G.I. Shenbrot, I.S. Khokhlova \& R. Poulin. 2004. Relationships between parasite abundance and the taxonomic distance among a parasite's host species: an example with fleas parasitic on small mammals. International Journal for Parasitology 34: 1289-1297.

Lamothe, R.A. 1997. Manual de técnicas para preparar y estudiar los parásitos de animales silvestres. AGT Editor, México, 43 pp.

Martín-Martín, A., E. Orduna-Malea, M. Thelwall \& E.D. López-Cózar. 2018. Google Scholar, Web of Science, and Scopus: a systematic comparison of citations in 252 subject categories. Journal of Informetrics, 12: 1160-1177.

McAllister, C., C. Bursey \& A. Burns. 2005. Gastrointestinal Helminths of Rafinesque's Bigeared Bat, Corynorhinus refinesquii (Chiroptera: Vespertilionidae), from southwestern Arkansas, U.S.A. Comparative Parasitology 72: 121-123.

McAllister, C.T., C.R. Bursey \& R.C. Dowler. 2007. Acanthatrium alicatai (Trematoda: Lecithodendriidae) from two species of bats (Chiroptera: Vespertilionidae) in southwestern Texas. The Southwestern Naturalist 52:597-600.

Mello, M.A.R., F.A. Rodrigues, L.D.F. Costa, W.D. Kissling, Ç.H. Şekercioğlu, F.M.D. Marquitti \& E.K.V. Kalko. 2015. Keystone species in seed dispersal networks are mainly determined by dietary specialization. Oikos 124: 1031-1039. 
Mendoza, L., J. Chávez \& M. Tantalean. 1997. Cestodos parásitos de murciélagos de Ica, Perú. Parasitología al día 20: 20-24.

Milano, A.F. 2016. Helmintofauna de murciélagos (Chiroptera) del nordeste argentino. PhD dissertation, Universidad Nacional de la Plata, La Plata, 168 pp.

Morand, S. \& P.H. Harvey. 2000. Mammalian metabolism, longevity and parasite species richness. Proceedings of the Royal Society of London B 267: 1999-2003.

Nogueira, M.R., S.P. de Fabio \& A.L. Peracchi. 2004. Gastrointestinal helminth parasitism in fruiteating bats (Chiroptera, Stenodermatinae) from western Amazonian Brazil. Revista de Biología Tropical 52: 387-392.

Ochoa, J. 1992. Venezuela's bats: A case for conservation. Bats 10: 10-13.

Oliva, M.E. \& J.L. Luque. 2010. Ictioparasitología marina en el sistema de afloramiento de la Corriente de Humboldt: desafíos para Neotropical Helminthology. Neotropical Helminthology 4: 99103.

Oviedo, M.C., G. Ramallo \& L.E. Claps. 2010. Una especie nueva de Cheiropteronema (Nematoda, Molineidae) en Artibeus planirostris (Chiroptera, Phyllostomidae) en la Argentina. Iheringia, Série Zoologia, 100: 242-246.

Pacheco, V., R. Cadenillas, S. Velazco, E. Salas \& U. Fajardo. 2007. Noteworthy bat records from the Pacific Tropical rainforest region and adjacent dry forest in northwestern Peru. Acta chiropterologica 9: 409-422.

Pacheco, V., R. Cadenillas, E. Salas, C. Tello \& H. Zeballos. 2009. Diversidad y endemismo de los mamíferos del Perú. Revista Peruana de Biología 16: $5-32$.

Patterson, B.D., V. Pacheco \& S. Solari. 1996. Distributions of bats along an elevational gradient in the Andes of South-eastern Peru. Journal of Zoology 240: 637-658.

Poulin, R. \& S. Morand. 2004. Parasite biodiversity. Smithsonian, Institution Press, Washington, D.C., 216 pp.

Pinheiro, M.C., C.C.D.U. Ribeiro, E.C. Lourenço, G.A. Landulfo, H.R. Luz, K.M. Famadas \& M.L.A. Rodrigues. 2013. Levantamento de enteroparasitos em morcegos através de técnica de centrífugo flutuação (Mammalia: Chiroptera) em área de Floresta Tropical. Neotropical Helminthology 7: 143-147.

Quintana, H., V. Pacheco \& E. Salas. 2009. Diversidad y conservación de los mamíferos de Ucayali, Perú. Ecología aplicada 8: 91-103.

Ramasindrazana, B., K. Dellagi, E. Lagadec, M. Randrianarivelojosia, S.M. Goodman \& P. Tortosa. 2016. Diversity, Host specialization, and geographic structure of filarial nematodes infecting Malagasy Bats. PLoS ONE 11: e0145709.

Reis, N.R., M.N. Fregonezi, A.L. Peracchi \& O.A. Shibatta. 2013. Morcegos do Brasil Guia de Campo. Technical Books Editora, Rio de Janeiro, 251 pp.
Rossi, P. \& C. Vaucher. 2002. Allintoshius bioccai n. sp. (Nematoda), a parasite of the bat Eptesicus furinalis from Paraguay, and new data on A. parallintoshius (Araujo, 1940). Parassitologia 44: 59-66.

Rózsa, L., J. Reiczigel \& G. Majoros. 2000. Quantifying parasites in samples of hosts. The Journal of Parasitology 86: 228-232.

Santos, C.P. \& D.I. Gibson. 2015. Checklist of the Helminth Parasites of South American Bats. Zootaxa 3937: 471-499.

Sarmiento, L., M. Tantaleán \& L. Huiza. 1999. Nemátodos parásitos del hombre y de los animales en el Perú. Revista peruana de parasitología 14: 9-65.

Scott, J. A., E.M. MacDonald \& B. Terman. 1951. A description of the stages in the life cycle of the filarial worm Litomosoides carinii. Journal of Parasitology $37: 425-432$

Solari, S. \& J.R. Baker. 2006. Mitochondrial DNA sequence, karyotypic, and morphological variation in the Carollia castena species complex (Chiroptera: Phyllostomidae) with description of a new species. Texas Tech University. Natural Science Research Laboratory, $16 \mathrm{pp}$.

Solari, S. \& V. Martínez-Arias. 2014. Cambios recientes en la sistemática y taxonomía de murciélagos Neotropicales (Mammalia: Chiroptera). Therya 5: 167-196.

Specian, R.D. \& J.E. Ubelaker. 1976. Redescription of a Nematode, Seuratum cancellation Chitwood, 1938, from Bats in Texas. Proceedings of the Helminthological Society of Washington 43: 59-65.

Tantaleán, M., L. Sarmiento \& A. Huiza. 1992. Digeneos (Trematoda) del Perú. Boletín de Lima (Perú) 80: 47-84.

Tantaleán, M. 2016. Helminth parasites in wild animals of Peru. New reports. Peruvian journal of parasitology 24:30-37.

Thatcher, V.E. 1993. Trematódeos Neotropicais. Instituto Nacional de Pesquisas da Amazônia, Manaus, $553 \mathrm{pp}$.

Ubelaker, J.E. 1970. Some observations on ecto- and endoparasites of Chiroptera. In: B.H. Slaughter, D.W. Walton (eds.) About bats, pp 247-261, Southern Methodist University, Dallas, Texas.

Vargas, C.M., R.R. Martínez \& V.M. Tantaleán 2009a. Cestodos de quirópteros del Parque Nacional Cerros de Amotape, Tumbes, Perú. Revista Peruana de Biología 16: 57-60.

Vargas, C.M., R.R. Martínez, V.M. Tantaleán, R. Cadenillas \& V. Pacheco. 2009b. Tricholeiperia peruensis n. sp. (Nematoda, Molineidae) del quiróptero Lophostoma silvicolum occidentalis (Phyllostomidae) en Tumbes, Perú. Revista Peruana de Biología 15: 23-26.

Vaucher, C. 1982a. Helminthes parasites du Paraguay III:Atriotaenia hastati n. sp. (Cestoda: Linstowiidae) parasite de Phyllostomus hastatus hastatus (Pallas). Bulletin de la Société Neuchâteloise des Sciences Naturelles 105: 155-161.

Vaucher, C. 1982b. Cestodes parasites de Chiroptéres en Amerique du Sud: révision de Hymenolepis elon- 
gatus (Rego, 1962) et description de Hymenolepis phyllostomi n. sp. Revue suisse de Zoologie 89: 451-459.

Vaucher, C. 1986. Cestodes parasites de Chiroptéres en Amerique du Sud II: Hymenolepis mazanensis n.sp., chez Saccopteryx bilineata (Temm.) et Rhynchonycteris naso (Wide-Neuwied) (Chiroptera: Emballonuridae) en Amazonie péruvienne. Revue suisse de Zoologie 93:817-821.

Vaucher, C. \& M.C. Durette-Desset. 1999. Histiostrongylus spinus n. sp. (Nematoda: Trichostrongylina), parásite de Phyllostomus discolor (Chiroptera: Phyllostomidae) et nouvelles dones sur les genres Histiostrongylus Molin, 1861 et Parahistiostrngylus Perez Vigueras, 1941. Revue suisse de Zoologie 106: 611-620.

Vitone, N.D., S. Altizer \& C.L. Nunn. 2004. Body size, diet and sociality influence the species richness of parasitic worms in anthropoid primates.
Evolutionary Ecology Research 6:183-189.

Walldorf, V. \& H. Mehlhorn. 2014. Bats: A glimpse on their astonishing morphology and lifestyle. In: S. Klimpel, H. Mehlhorn (eds.) Bats (Chiroptera) as vectors of diseases and parasites. Springer-Verlag, Berlin Heidelberg, 7-24.

Williams, R. 1948. Studies on the Life Cycle of Litomosoides carinii, Filariid Parasite of the Cotton Rat, Sigmodon hispidus litoralis. The Journal of Parasitology 34: 24-43.

Wilson, A.J., E.R. Morgan, M. Booth, R. Norman, S.E. Perkins, H.C. Hauffe, N. Mideo, J. Antonovics, H. McCallum \& A. Fenton. 2017. What is a vector? Philosophical Transactions of Royal Society B 372: 20160085

Wund, M. \& P. Myers. 2005. "Chiroptera" (On-line). Animal diversity web. http://animaldiversity. ummz.umich.edu/accounts/Chiroptera. Accessed on: 2018-01-30

Doi: 10.22179/REVMACN.22.675

Recibido: 5-II-2019

Aceptado: 9-IV-2020 